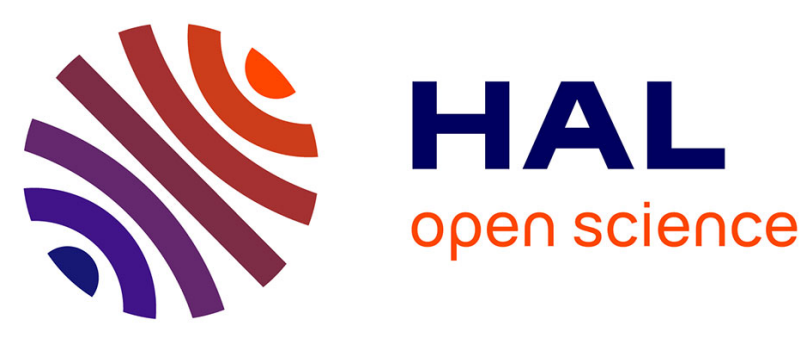

\title{
Selective and quantitative nitrate electroreduction to ammonium using a porous copper electrode in an electrochemical flow cell
}

Rawa Abdallah, Florence Geneste, Thierry Labasque, Hayet Djelalc, Florence Fourcade, Abdeltif Amrane, Samir Taha, Didier Floner

\section{To cite this version:}

Rawa Abdallah, Florence Geneste, Thierry Labasque, Hayet Djelalc, Florence Fourcade, et al.. Selective and quantitative nitrate electroreduction to ammonium using a porous copper electrode in an electrochemical flow cell. Journal of electroanalytical chemistry and interfacial electrochemistry, 2014, 727, pp.148-153. 10.1016/j.jelechem.2014.06.016 . insu-01022586

\section{HAL Id: insu-01022586 \\ https://hal-insu.archives-ouvertes.fr/insu-01022586}

Submitted on 10 Jul 2014

HAL is a multi-disciplinary open access archive for the deposit and dissemination of scientific research documents, whether they are published or not. The documents may come from teaching and research institutions in France or abroad, or from public or private research centers.
L'archive ouverte pluridisciplinaire HAL, est destinée au dépôt et à la diffusion de documents scientifiques de niveau recherche, publiés ou non, émanant des établissements d'enseignement et de recherche français ou étrangers, des laboratoires publics ou privés. 
Selective and quantitative nitrate electroreduction to ammonium using a porous copper electrode in an electrochemical flow cell

Rawa Abdallah $^{\mathrm{a}, \mathrm{b}, \mathrm{c}}$, Florence Geneste $^{\mathrm{a}}$, Thierry Labasque ${ }^{\mathrm{e}}$, Hayet Djelal ${ }^{\mathrm{c}, \mathrm{d}}$, Florence Fourcade ${ }^{\mathrm{c}}$ Abdeltif Amrane ${ }^{c}$, Samir Taha $^{\mathrm{b}}$, Didier Floner ${ }^{\mathrm{a}^{*}}$

${ }^{a}$ Université Rennes 1, UMR 6226, Equipe MaCSE, Campus de Beaulieu, Rennes Cedex, France

${ }^{b}$ Université Libanaise, EDST, Centre Azm pour la Recherche en Biotechnologie et ses Applications, LBA3B, Rue El Mitein, Tripoli, Liban

${ }^{c}$ Ecole Nationale Supérieure de Chimie de Rennes, UMR 6226, Campus de Beaulieu, Rennes

Cedex, France

${ }^{d}$ Ecole des Métiers de l'Environnement, Campus de Ker Lann, 35170 Bruz, France

${ }^{e}$ Géosciences Rennes-OSUR, UMR CNRS 6118, université de Rennes 1, France

*Corresponding author. Tel: +33 02232350 10; fax: +330223235967.

E-mail address: didier.floner@univ-rennes 1.fr (D. Floner). 


\begin{abstract}
The aim of this work was to set up a novel electrochemical system allowing an efficient transformation of concentrated nitrate solutions to ammonium and which can be subsequently implemented on a large scale application. First, this paper describes the preparation of a porous copper modified electrode by successive electrodeposition of nickel then copper on a graphite felt of large specific surface area. Homogeneous $\mathrm{Cu}$ coating of all fibres in the 3D porous structure was successfully obtained using low concentrations of copper salts and high applied current intensities. The porous copper electrode was then used in a flow electrochemical process to achieve a selective and quantitative transformation of concentrated nitrate into ammonium. Different electrolytic solutions, slightly acid (acetate buffer) or neutral (phosphate buffer), and flow rates were investigated. The nitrate solution was quantitatively reduced into $\mathrm{NH}_{4}{ }^{+}$with high selectivity in only one pass through the electrode. When the applied current was similar to the theoretical one, the maximum selectivity $(96 \%)$ and the best current efficiency $(72 \%)$ for $\mathrm{NH}_{4}{ }^{+}$ formation were reached at $\mathrm{pH} 7.2$ with a flow rate of $2 \mathrm{~mL} \mathrm{~min}^{-1}$. The obtained ammonium solution can be subsequently used either as a potential nitrogen source during microbial culture or simply as a fertilizer.
\end{abstract}

\title{
Keywords: porous copper cathode; nitrates electroreduction; ammonium; electrochemical
}

\section{flow cell}




\section{Introduction}

Nitrate ions $\left(\mathrm{NO}_{3}{ }^{-}\right)$contamination of ground and surface water resources has become a serious problem around the world. Removing nitrate is very important for various reasons. (i) Nitrate water pollution disturbs public health and ecological equilibrium [1]. Consuming high $\mathrm{NO}_{3}^{-}$ concentrations in drinking water can cause serious health problems in humans such as the "blue baby syndrome" in infants, liver damage and cancer [2]. (ii) By considering the ecological balance, excess of nitrate favor eutrophication of lakes, rivers and seas, manifested through uncontrolled algal growth $[3,4]$. WHO and European community set stringent limits for the $\mathrm{NO}_{3}{ }^{-}$ concentrations in surface and groundwater to $50 \mathrm{mg} \mathrm{L}^{-1}$ and $25 \mathrm{mg} \mathrm{L}^{-1}$ respectively [5].

Nowadays, many processes such as biological and physiochemical methods are used for nitrate removal from contaminated water but show drastic limits. Biodenitrification is considered as the method of choice [6,7]. However, this method is slow, requires continuous monitoring of microorganism's growth (carbon source, $\mathrm{pH}$ and temperature control) [8]. Furthermore, it can be used only at concentrations lower than $1000 \mathrm{mg} \mathrm{NO}_{3}^{-} \mathrm{L}^{-1}$, since higher ones can be poisonous to the bacteria [9]. Physicochemical processes such as ion exchange, reverse osmosis and electrodialysis are costly [10] and produce secondary brine wastes, because the nitrate are only separated but not destroyed [11]. Thus, these methods lead to concentrated effluents of nitrates $(\geq$ $3 \mathrm{~g} \mathrm{~L}-1)[12]$ that are very difficult to treat.

Electrochemical nitrate treatment can offer a promising and attractive solution due to its advantages regarding low cost effectiveness, convenience, ability to treat highly concentrated nitrate effluents and environmental friendliness [13-15] particularly if the resulting product is $\mathrm{N}_{2}$ gas [16]. An ideal electrochemical method must combine a high rate of reduction, a selective conversion of nitrate to the desired product, a high current efficiency (\% CE) and low energy consumption [17]. 
Almost all recent electrochemical studies aim to convert nitrate to the non toxic nitrogen gas [18]. In this context paired electrolysis seems to be the most efficient and hence the most widely used electrochemical method [6,19-21]. It consists to reduce $\mathrm{NO}_{3}{ }^{-}$to ammonium at the cathode, and then the produced ammonium is oxidized at the anode into $\mathrm{N}_{2}$ with or without the contribution of hypochlorite ions $\left(\mathrm{ClO}^{-}\right)$, which results from the oxidation of chloride ions on the anode [22]. However, the main problem in this approach is that the transformation of $\mathrm{NO}_{3}^{-}$to nitrogen is a difficult reaction since both the rate and the selectivity of the reduction of nitrate to ammonium are usually low, due to the large number of by-products such as $\mathrm{NO}_{2}, \mathrm{NO}_{2}^{-}, \mathrm{NO}, \mathrm{N}_{2} \mathrm{O}, \mathrm{NH}_{2} \mathrm{OH}$, $\mathrm{NH}_{3}, \mathrm{NH}_{2} \mathrm{NH}_{2}$ involved in the reduction mechanism [18].

As the products of the nitrate electroreduction are critically dependent on the nature of the cathode material [23-25], this fact led to the search for selective and active cathode materials. Many solid electrodes have been studied including Pb, Ni [26], Cu [27], Pt [28], Ru [29], Ir [30], $\mathrm{Rh}$ [31] and $\mathrm{Fe}$ [32]. Among these materials, copper is known to be the most efficient electrocatalyst for nitrate electroreduction producing ammonium as a final product [33-35]. Thus, electrochemical treatment of nitrates on pure $\mathrm{Cu}$ cathodes $[33,36,37]$ or $\mathrm{Cu}$ alloys $[21,38-40]$ has been widely studied. But all these investigations are analytical studies and/or deal with relatively low nitrate concentrations [39]. Moreover, the main problem in the electroreduction of nitrates on solid electrodes is the low reduction rate [7] owing to the low mass transport. This considerable drawback limits their use for large scale applications.

The use of a flow electrochemical cell with a graphite felt as porous electrode can resolve the problem related to the mass transport. This system has the advantage of oxidizing/reducing a large amount of substrate in short times, allowing quantitative electrochemical treatments [41]. The major advantages of graphite felt as porous electrode material are its high specific surface area, ranging from $0.7 \mathrm{~m}^{2} \mathrm{~g}^{-1}$ to $2000 \mathrm{~m}^{2} \mathrm{~g}^{-1}$, the low cost and the availability of these materials. 
But unfortunately, graphite felt is a poor electrode for the selective reduction of nitrates to ammonium. Hence, it's necessary to enhance its selectivity toward ammonium formation.

It is interesting to note that among the various nitrate electroreduction by-products (ie. $\mathrm{N}_{2}, \mathrm{~N}_{2} \mathrm{O}$, $\mathrm{N}_{2} \mathrm{O}^{-}, \mathrm{NH}_{4}^{+}$), ammonium has the highest economic value. It has an important potential as fertilizers [42-44] and as nitrogen source for microorganism cultures producing biohydrogen [45-47]. The use of cheap inorganic nitrogen source appears relevant from an economical point of view, contrarily to organic nitrogen sources which are often more expensive [48]. For this reason, an electroreduction of nitrate to $\mathrm{NH}_{4}{ }^{+}$over copper cathode can be considered as an attractive way, since it allows not only pollutant treatment, nitrate, but also possible valorization of the treated effluent.

Therefore, the first objective of the present study was the preparation of a new cathode material, a porous copper electrode by successive electrodeposition of nickel then copper on a graphite felt. A homogeneous coating of all fibres of thick graphite felts was obtained. The method leads to the formation of a copper modified graphite felt $(\mathrm{CuGF})$ of high specific surface area and low weight. The second objective was the use of the CuGF electrode for the electrochemical reduction of a concentrated nitrate solution $\left(3 \mathrm{~g} \mathrm{NO}_{3}^{-} \mathrm{L}^{-1}\right)$ into ammonium in a divided flow cell. Results show that the system combining the performances of the flow cell and the CuGF electrode lead to high chemical yields and current efficiencies.

\section{Experimental procedure}

\section{1. $C u G F$ working electrode: preparation and characterization}

Nickel (II) sulfate heptahydrate $\left(\mathrm{Ni}\left(\mathrm{SO}_{4}\right) \cdot 7 \mathrm{H}_{2} \mathrm{O}\right)$; copper (II) sulfate pentahydrate $\left(\mathrm{Cu}\left(\mathrm{SO}_{4}\right) .5 \mathrm{H}_{2} \mathrm{O}\right) 99 \%$; boric acid $99 \%$ and sodium sulfate anhydrous $99 \%$ were supplied by ACROS. Graphite felt (RVG 4000) used as metal electroplating support was purchased from 
MERSEN (Paris La Defense, France). Its specific surface area measured by the BET method was $0.7 \mathrm{~m}^{2} \mathrm{~g}^{-1}$, its density was $0.088 \mathrm{~g} \mathrm{~cm}^{-3}$ and its carbon yield was $99.9 \%$.

Graphite felt modification consisted in two steps. First, nickel was electrochemically deposited on the graphite fibres of the graphite felt (diameter: $5.6 \mathrm{~cm}$ and thickness $0.3 \mathrm{~cm}$ ) according to a previously described method [49]. Secondly, the electrodeposition of copper was performed on the nickel modified graphite felt according to the conditions described in Table 1.

Table 1

$1 \mathrm{~L}$ of electrolytic solution (copper sulfate $\left(3 \times 10^{-2} \mathrm{M}\right)$; sodium sulfate $(0.5 \mathrm{M})$; boric acid $(0.25$ M)) was flowed through the porous electrode in a home-made flow cell (Fig.1). To obtain a good homogeneity of the potential distribution in the three dimensional working electrode, the $\mathrm{Ni}$ modified graphite felt was located between two counter-electrodes (platinum grids) [50] and the electrical contact with the working electrode was performed with a copper wire. The electroplating experiments have been realized without adding cationic exchange membranes. A periodically changing current (on-pulse: $0.1 \mathrm{~A}$ for $1 \mathrm{~cm} 3$ of felt, off-pulse: $0 \mathrm{~A}$, see table 2 for the duration of the pulses) was applied between the electrodes, using a power Lab/4SP (Scope version 3.6.10, AD Instruments) coupled to an EG\&G Princeton Applied Research model 362 operating under galvanic conditions. The flow rate of the electrolytic solution was maintained at $5 \mathrm{~mL} \mathrm{~min}^{-1}$ and the $\mathrm{pH}$ of the electrolyte solutions was adjusted with solutions of $\mathrm{H}_{2} \mathrm{SO}_{4}(0.5 \mathrm{M})$ or $\mathrm{NaOH}(5 \mathrm{M})$. The full electrodeposition time was 240 min without taking into account the relaxation time (Table 2).

\section{Table 2}


The SEM (scanning electron microscope) micrographs were obtained with a Jeol 630v1F (9 kv) microscope.

\subsection{Flow electrolyses}

$1 \mathrm{~L}$ of nitrate solutions $\left(3 \mathrm{~g} \mathrm{~L}^{-1}\right)$ were prepared by dissolving potassium nitrate $\left(\mathrm{KNO}_{3}\right)$ in acetate buffer pH $4.8\left(\mathrm{CH}_{3} \mathrm{COOH} / \mathrm{CH}_{3} \mathrm{COO}^{-} 0.5 \mathrm{M} / 0.5 \mathrm{M}\right)$ or phosphate buffer $\mathrm{pH} 7.2\left(\mathrm{H}_{2} \mathrm{PO}_{4}^{-} / \mathrm{HPO}_{4}{ }^{2-}\right.$ 0.25 M / 0.25 M). Electrolyses were performed at constant current in a flow cell (Fig.1) equipped with two exchange membranes (cationic and anionic) (Ionac 3470 -Lanxess SAS, Courbevoie, France)

Fig.1.

The flow rate was monitored by a Gilson minipuls 2 peristaltic pump and the current by a homemade power supply (30 V/ 3A). The cell was thoroughly rinsed with distilled water before each experiment. The applied current was calculated from the Faraday law (Eq. 1) ) [41].

$\mathrm{i}(\mathrm{A})=\left[\mathrm{NO}_{3}{ }^{-}\right]_{\mathrm{t}=0} \times \mathrm{d} \times\left(10^{-3} / 60\right) \times \mathrm{n} \times \mathrm{F}$

where $\left[\mathrm{NO}_{3}{ }^{-}\right]_{\mathrm{t}=0}$ is the initial concentration of nitrates $\left(\mathrm{mol} \mathrm{L}{ }^{-1}\right), \mathrm{d}$ is the flow rate $\left(\mathrm{mL} \mathrm{mn}^{-1}\right), \mathrm{F}$ is the Faraday's constant $\left(96,487 \mathrm{C} \mathrm{mol}^{-1}\right)$ and $\mathrm{n}$ is the number of exchanged electrons $\left(8 \mathrm{e}^{-}\right)$for the conversion of nitrate to ammonium.

\subsection{Analytical methods}

Every $30 \mathrm{~min}, 5 \mathrm{~mL}$ of samples were collected from the electrolytic medium and filtered through a $0.45 \mu \mathrm{m}$ membrane before analysis. $\mathrm{NO}_{3}{ }^{-}$and $\mathrm{NO}_{2}{ }^{-}$concentrations were measured using ion chromatography (Dionex120) equipped with a Dionex IonPac AS18A Anion Exchange column 
and a chemical suppressor (ASR 300-ultra $4 \mathrm{~mm}$ ), using $8 \mathrm{M} \mathrm{KOH}$ as eluent at a flow rate of $1.04 \mathrm{~mL} \mathrm{~min}{ }^{-1} . \mathrm{NH}_{4}{ }^{+}, \mathrm{N}_{2} \mathrm{H}_{4}$ and $\mathrm{NH}_{2} \mathrm{OH}$ concentrations in solution were spectrophotometrically determined by an UV-vis spectrophotometer (Cary-1E, Varian) as reported elsewhere [51-53]. Nitrous oxide gas $\left(\mathrm{N}_{2} \mathrm{O}\right)$ were obtained by headspace equilibrium extraction and analyzed by $\mu \mathrm{GC} / \mathrm{TCD}$ (Agilent Micro GC3000 (SRA) Instruments), pure gases were used as calibration standards [54]. The $\mathrm{pH}$ was measured using a 9165BN pH electrode connected to an Orion-828 pH Analyzer (Orion Research Inc., Beverly, MA, USA).

\subsection{Definition of the parameters}

The performance of the flow cell was evaluated from the electrochemical conversion of nitrates into ammonium in one pass through the flow cell at room temperature, using the following parameters: the normalized percentage of nitrate removal or the conversion yield (\% $\tau)$ (Eq. 2), the chemical yield of reduction products (ammonium and nitrite yields) (\% $\left.X_{\mathrm{i}}\right)($ Eq. 3 ) and the selectivity based on the ammonium yield (\% $\left.\mathrm{S}_{\mathrm{NH} 4+}\right)$ (Eq. 4), [19].

$\% \tau=\left(\left[\mathrm{NO}_{3}{ }^{-}\right]_{\mathrm{t}=0}-\left[\mathrm{NO}_{3}{ }^{-}\right]_{\mathrm{t}}\right) \times 100 /\left[\mathrm{NO}_{3}{ }^{-}\right]_{\mathrm{t}=0}$

$\% X_{\mathrm{NH} 4+}=\left(\left[\mathrm{NH}_{4}^{+}\right]_{\mathrm{t}} \times 100\right) /\left[\mathrm{NO}_{3}^{-}\right]_{\mathrm{t}=0}$ and \% $X_{\mathrm{NO} 2-}=\left(\left[\mathrm{NO}_{2}{ }^{-}\right]_{\mathrm{t}} \times 100\right) /\left[\mathrm{NO}_{3}{ }^{-}\right]_{\mathrm{t}=0}$

$\% \mathrm{~S}_{\mathrm{NH} 4+}=\left(\left[\mathrm{NH}_{4}^{+}\right]_{\mathrm{t}} \times 100\right) /\left(\left[\mathrm{NO}_{3}{ }^{-}\right]_{\mathrm{t}=0}-\left[\mathrm{NO}_{3}{ }^{-}\right]_{\mathrm{t}}\right)=\left(\% X_{\mathrm{NH} 4+} \times 100\right) /(\% \tau)$

The current-denitrification efficiency (current efficiency (\% CE)), calculated based on the cathodic current efficiency is defined by equation 5:

$\% \mathrm{CE}=\left(\left(\left[\mathrm{NH}_{4}^{+}\right]_{\mathrm{t}} \times \mathrm{n} \times \mathrm{F} \times \mathrm{V}_{\mathrm{t}}\right) /(\mathrm{i} \times \mathrm{t})\right) \times 100$

where $[X]_{t=0}$ and $[X]_{t}$ are the concentrations of $X$ in solution at initial and time $t(s), V_{t}(L)$ is the electrolyzed volume at time t.

All the concentrations are in $\mathrm{mol} \mathrm{L}^{-1}$ and $1 \mathrm{~F}=96,487 \mathrm{C} \mathrm{mol}^{-1}$. 


\section{Results and discussion}

\subsection{Galvanostatic method}

Metal electrodeposition on porous material of high surface area such as graphite felt is not easy due to the strong heterogeneity of potential distribution inside the material $[55,56]$. At constant current, electrical potential rapidly decreases along the depth of the material. Metallization only appears at the external face of the material with formation of a metallic crust more or less rapidly according to the metal salts concentration. To avoid this phenomenon we developed a galvanostatic method well-adapted to the 3-D electrode.

Two fundamental points are necessary to achieve homogeneous coating of the fibres (i) an electrodeposition solution containing the metal salts in low concentration (around $10^{-2} \mathrm{M}$ ) and (ii) a strong current (around $100 \mathrm{~mA}$ per $\mathrm{cm}^{3}$ of felt). Thereby diffusion-limited currents are quickly reached on the external fibres limiting the rate of electrodeposition on the external face of the graphite felt. Consequently, the excess of current allows the electrodeposition on other fibres located inside the felt. As soon as the diffusion-limited current is reached on a fibre, the electrodeposition process is accelerated on another fibre located farther from the electrode surface. Due to the decrease of the metallic cations concentration in the vicinity of the fibres, hydrogen evolution occurs and becomes more and more important. An alternating current was therefore employed with long relaxation time to stop hydrogen evolution and reduce the local decrease of metallic cations concentration inside the felt.

\subsection{Copper electrodeposition}

Copper electrodeposition was achieved in the flow cell (Fig.1) at a constant flow rate (d) of $5 \mathrm{~mL}$ $\min ^{-1}$ and with a working electrode of volume $\mathrm{V}=7.5 \mathrm{~cm}^{3}$. Unfortunately, first attempts to perform electrodeposition of copper on graphite felt led to non-homogeneous coating of the 
fibres. SEM images showed only small and friable particles of metallic copper, scattered along the fibres whereas copper powder predominated inside the felt. This result underlines the weak adherence between metallic copper and graphite. Since copper is known to efficiently adhere to metallic surfaces, the graphite felt was first covered by a homogeneous film of nickel (Fig. 2 a) according to a previously reported method [49].

Fig. 2.

The flow rate (d) was kept to $5 \mathrm{~mL} \mathrm{~min}^{-1}$ and the volume of the working electrode to $7.5 \mathrm{~cm}^{3}$. When a constant current is applied, the maximum time allowing the complete regeneration of the solution inside the felt is $t_{\max }=\mathrm{V} / \mathrm{d}$. Due to the convection inside the felt resulting from percolation, the regeneration time is lower than $\mathrm{t}_{\max }$ and depends on the initial concentration of copper. With this tendency in mind, different electrodeposition experiments were performed, varying the concentration of copper and the on-pulse and off-pulse times. The most relevant one are presented in Table 2. The best conditions are given in experiment 4 corresponding to a copper concentration of $3 \times 10^{-2} \mathrm{M}$ with an off-pulse time ( $\left.\mathrm{t}_{\mathrm{off}}\right)$ of $35 \mathrm{~s}$ and a on-pulse time $\left(\mathrm{t}_{\mathrm{on}}\right)$ of $15 \mathrm{~s}$. We found that when $t_{\text {off }}$ was around $t_{\max } / 3$ the renewal of the copper solution inside the felt was good. Moreover, a ratio $\mathrm{t}_{\mathrm{on}} / \mathrm{t}_{\text {off }}$ less than 2.3 led to a rapid decrease of the copper concentration inside the felt. Thus, hydrogen evolution became preponderant leading to an increase of the solution $\mathrm{pH}$ inside the felt and precipitation of copper hydroxide. In these conditions, a poor quality of copper deposition was obtained with a low current efficiency. Homogeneous copper electroplating was achieved with a current efficiency higher than $50 \%$ for a ratio $t_{\text {off }} / t_{\text {on }}$ upper to 2.3. A decrease of $t_{\text {on }}$ led to higher values of current efficiencies but increased the full electrolysis time. 
The homogeneity of the copper coating was checked by SEM. Fig. 2 b, c and d show copper coating fibres located inside the felt and cut transversally. The electrodeposition method led to a copper film with an average thickness around $2 \mu \mathrm{m}$ that follows the shape of the graphite fibres. This layer of copper was even visible to the naked eye. As seen in Fig. 2b and c the high porosity of the material was conserved. The copper deposit has a granular aspect and consists in crystallites of different sizes assembled on the surface of the fibres (Fig. 2c). Fig. $2 d$ shows the two successive layers of nickel and copper obtained after the two successive electrodepositions. Graphite felt is visible on the lower left quarter of the microphotograph. On the right from the bottom to the top of the microphotograph appear the nickel film on the graphite fibre and then the copper film deposited on the nickel layer. Since the brightness of nickel is very different from that of copper, SEM images clearly highlight the homogeneous structure of the copper deposit. The specific surface area of the copper modified graphite felt was estimated by BET to $2 \mathrm{~g} \mathrm{~m}^{-2}$. The average density of deposited copper was about $0.265 \mathrm{~g} \mathrm{~cm}^{-3}$ of felt. Consequently, the electrodeposition method led to the preparation of a CuGF electrode having a high specific surface and a low density; this latter electrode was used afterward as a cathode for electrochemical denitrification studies.

\subsection{Nitrate reduction}

Electrolysis of nitrate was performed in a single passage in a homemade flow cell (Fig.1) containing a porous copper electrode of $5.6 \mathrm{~cm}$ diameter and $0.3 \mathrm{~cm}$ thickness corresponding to a volume of $7.8 \mathrm{~cm}^{3}$. The experiments were performed with a high concentration of synthetic nitrate solutions ( $\left.3 \mathrm{~g} \mathrm{NO}_{3}^{-} \mathrm{L}^{-1}\right)$ to be in conditions similar to those of real effluents obtained after a classical physicochemical denitrification of polluted water [12]. The following parameters 
for nitrate electroreduction were studied: (1) $\mathrm{pH}$ (acid and neutral); (2) flow rate (1mL min ${ }^{-1}, 2$ $\mathrm{mL} \min ^{-1}$ and $\left.3 \mathrm{~mL} \mathrm{~min}^{-1}\right)$; (3) applied current.

Reactions (1), (2) and (3) take place at the cathode and produce more hydroxyl anions than the protons formed at the anode (reaction 4). Consequently, the $\mathrm{pH}$ value increases during the electrolysis more or less strongly depending on the chemical yield of ammonium ( $\left.\% X_{\mathrm{NH} 4+}\right)$.

$$
\begin{array}{cll}
\mathrm{NO}_{3}^{-}+8 \mathrm{e}^{-}+10 \mathrm{H}_{2} \mathrm{O} & \rightleftharpoons & \mathrm{NH}_{4}^{+}+3 \mathrm{H}_{2} \mathrm{O}+10 \mathrm{OH}^{-} \\
2 \mathrm{NO}_{3}{ }^{-}+6 \mathrm{H}_{2} \mathrm{O}+10 \mathrm{e}^{-} & \rightleftharpoons & \mathrm{N}_{2}+12 \mathrm{OH}^{-} \\
8 \mathrm{H}_{2} \mathrm{O}+8 \mathrm{e}^{-} & \rightleftharpoons \begin{array}{l} 
\\
4 \mathrm{H}_{2}+8 \mathrm{OH}^{-} \\
12 \mathrm{H}_{2} \mathrm{O}
\end{array} & \rightleftharpoons \mathrm{O}_{2}+8 \mathrm{H}_{3} \mathrm{O}^{+}+8 \mathrm{e}^{-}
\end{array}
$$

This behavior amplified by the high nitrate concentration led us to choose buffered solutions as electrolytic media. The $\mathrm{pH}$ of the solution was fixed to 4.8 or 7.2 , since at $\mathrm{pH}$ higher than 8 , a slight corrosion of copper occurred. Indeed, after electrolysis at $\mathrm{pH} 8$, a light blue coloration of the solution appeared when the current was no more applied, due to the formation of copper salts in the solution. As soon as produced ammonia was evacuated out of the copper electrode, the coloration disappeared, showing that the corrosion process probably involved the formation of $\mathrm{Cu}\left(\mathrm{NH}_{3}\right)_{4}{ }^{2+}$.

\subsubsection{Effect of flow rate and $\mathrm{pH}$ on electroreduction efficiency}

Flow rate does not seem to have a great influence on the results of electrolysis. It is obvious from table 3 that for flow rates ranging from 1 to $3 \mathrm{~mL} \mathrm{~min}^{-1}$, the conversion yield of nitrate $(\% \tau)$ was more than $70 \%$ and not quantitative mainly due to hydrogen evolution (reaction 3).

\section{Table 3}

Indeed, during the electrolysis, by-products such as hydrazine $\left(\mathrm{H}_{2} \mathrm{~N}-\mathrm{NH}_{2}\right)$, nitrous oxide $\left(\mathrm{N}_{2} \mathrm{O}\right)$ and hydroxylamine $\left(\mathrm{H}_{2} \mathrm{~N}-\mathrm{OH}\right)$ were not detected. Only the presence of a very small amount of 
nitrite can be noticed (Table 3). Beyond a flow rate of $3 \mathrm{~mL} \mathrm{~min}^{-1}$, the formation of gaseous hydrogen became important and prevented the electrolysis due to an accumulation of gas in the working compartment.

The selectivity of the reaction 1 was strongly influenced by the $\mathrm{pH}$ of the solution, as seen with $\% \mathrm{~S}_{\mathrm{NH} 4+}$ in table 3 . The nitrate reduction to ammonium is quasi quantitative in neutral solution but significantly decreases in acidic solution, probably due to the formation of a small quantity of gaseous nitrogen (reaction 2) [7]. The maximum ammonium selectivity of $96 \%$ was obtained

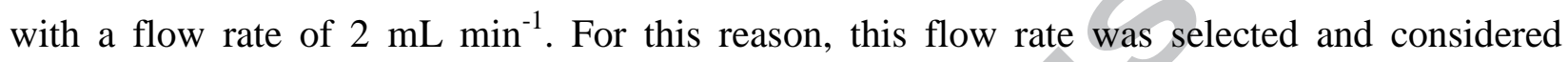
thereafter.

It is interesting to note that all experiments were performed with the same copper porous electrode and that no degradation of this material was observed, showing a high stability and durability of the electrode

\subsubsection{Effect of current and $\mathrm{pH}$ on electroreduction efficiency}

Several experiments were performed using different ratios, $\mathrm{R} i$, of applied current $\left(\mathrm{i}_{\text {app }}\right)$ different to the theoretical calculated intensity $\left(\mathrm{i}_{\mathrm{th}}\right)$ and linked by the ratio $\left(R_{i}=\mathrm{i}_{\mathrm{app}} / \mathrm{i}_{\mathrm{th}}\right)$. As mentioned above (section 3.3.1), all electrolyses were carried out with a flow rate of $2 \mathrm{~mL} \mathrm{~min}^{-1}$ and the results are given in Table 4.

Table 4

The conversion yields of nitrate at $\mathrm{pH} 7.2$ and 4.8 were similar and increased gradually with the applied current. However, it is interesting to take into account the apparent conversion yield $\left(\% \tau_{\text {app }}\right)$ expressed according to the following relation:

$\% \tau_{\text {app }}=\% \tau /\left(\left[\mathrm{NO}_{3}{ }^{-}\right]_{\mathrm{app}} /\left[\mathrm{NO}_{3}{ }^{-}\right]_{\mathrm{t}=0}\right)$ 
where $\left[\mathrm{NO}_{3}{ }^{-}\right]_{\mathrm{t}=0}$ is the initial nitrates concentration and $\left[\mathrm{NO}_{3}{ }^{-}\right]_{\text {app }}$ the theoretical maximum amount of nitrate reduced by applying $\mathrm{i}_{\text {app }}$. For $\mathrm{i}_{\text {app }}<\mathrm{i}_{\text {th }}$ the ratio $\left[\mathrm{NO}_{3}\right]_{\text {app }}=\left[\mathrm{NO}_{3}{ }^{-}\right]_{\mathrm{t}=0}$ is equal to the ratio $R_{i}$ and for $\mathrm{i}_{\text {app }}>\mathrm{i}_{\mathrm{th}},\left[\mathrm{NO}_{3}{ }^{-}\right]_{\text {app }}=\left[\mathrm{NO}_{3}{ }^{-}\right]_{\mathrm{t}=0}$ and $\% \tau_{\text {app }}=\% \tau$.

The experimental results show that the lower is the applied current, the higher is the apparent conversion yield. A\% $\tau_{\text {app }}$ close to $100 \%$ was obtained when the ratio $R_{i}$ was equal to 0.5 , corresponding to the reduction of $50 \%$ of the initial amount of nitrate. Higher $R_{i}$ values led to an increase of the amount of the nitrate reduced but decrease the $\% \tau_{\text {app }}$ (Table 4).This is due to the apparition of the electrochemical reduction of water, leading to hydrogen evolution. The behavior of the selectivity was first similar for the two solutions $(\mathrm{pH} 4.8$ and 7.2) for $R i=0.5$ and increased from for $R i=0.5$ to 1 . For higher values of $R i$, the selectivity was remained the same for $\mathrm{pH} 7.2$ but, decreased slightly for $\mathrm{pH} 4.8$. Indeed, in neutral solution, the selectivity was close to $100 \%$ for $R_{i} \geq 1$, showing that the secondary reaction 2 no more occurred. In acidic solution, a maximum selectivity of $75 \%$ was obtained for $R_{i}=1$, due to the formation of a constant amount of gaseous nitrogen.

The current efficiency calculated from the reduction of nitrate into ammonium was maximum for $R_{i}$ close to 0.9 (Fig, 3 ) and equal to $72 \%$ and $50 \%$ for $\mathrm{pH} 7.2$ and $\mathrm{pH} 4.8$, respectively.

Fig. 3.

As seen above, the formation of nitrogen (reaction 2) and hydrogen (reaction 3) are the main secondary reactions. In acidic solution, whatever the value of $R_{i}$, nitrogen formation always happened, decreasing the current efficiency. But in neutral solution, nitrogen formation stopped when $R_{i}$ reached the value of 1 and then only hydrogen formation limited the current efficiency. 
Thus, the maximum value of current efficiency for $R_{i}=0.9$ corresponds to the end of nitrogen formation. Beyond this value, the formation of hydrogen is more and more important and affects the current efficiency (Fig.3).

It is important to note that the conversion yield and current efficiency are mainly limited by contact probability between nitrates ions and metallic fibres. Consequently, they depend on the porosity and the surface area of the electrode. Thus, in neutral solution, the current efficiency should be improved by using a porous copper electrode of larger surface area.

\section{Conclusion}

Porous copper electrode has been prepared by copper electrodeposition onto nickel modified graphite felt according to an original process combining an optimized galvanostatic method and flowing conditions. Low concentrations of metal salts and high applied current were necessary to achieve a homogeneous metallic coating of the fibres. These results demonstrate the possibility to deposit a new metal layer on already metalized graphite felt and open the door for the preparation of metallic felt of different nature such as cobalt, tin and bismuth. One of the interests of these porous materials is their catalytic properties. Thus, the use of copper modified graphite felt as a cathode in an electrochemical flow cell allowed a selective and quantitative reduction of nitrate solutions of high concentration $\left(3 \mathrm{~g} \mathrm{NO}_{3} \mathrm{~L}^{-1}\right)$ into $\mathrm{NH}_{4}{ }^{+}$. A maximum $\mathrm{NH}_{4}{ }^{+}$selectivity $\left(\% \mathrm{~S}_{\mathrm{NH} 4+}\right)$ of $96 \%$ and a high current efficiency for $\mathrm{NH}_{4}{ }^{+}$formation (\% CE $72 \%$ ) were recorded with a solution of $\mathrm{pH} 7.2$, a flow rate of $2 \mathrm{~mL} \mathrm{~min}^{-1}$ and a ratio $\left(\mathrm{i}_{\text {app }} / \mathrm{i}_{\text {th }}\right.$ ) equal to 1 . These results are suitable for nitrate treatment on a larger scale application.

In summary in this report we set up a novel electrochemical process allowing an efficient conversion of very concentrated nitrate solution to ammonium in neutral medium. 
The feasibility of the use of the ammonium solution, obtained by the present process, to produce biohydrogen in dark fermentation via heat treated anaerobic activated sludge will be carried out in continuity of the present work.

\section{Acknowledgements}

The authors are thankful to the Lebanese Social Association Azm and Saadeh, Doctoral school (SDLM)) and the CNRS for the financial support during this work. We are also grateful to Mr J. Le Lannic for microphotographs and we thank O. Merdrignac and N. Pontais for BET measurements.

\section{References}

[1] A. Bhatnagar, M. Sillanpää, A review of emerging adsorbents for nitrate removal from water, Chem. Eng. J. 168 (2011) 493-504.

[2] T.Y.K. Chan, Vegetable-borne nitrate and nitrite and the risk of methaemoglobinaemia, Toxicol. Lett. 200 (2011) 107-108.

[3] O. Primo, M.J. Rivero, A.M. Urtiaga, I. Ortiz, Nitrate removal from electro-oxidized landfill leachate by ion exchange, J. Hazard. Mater. 164 (2009) 389-393.

[4] B. Talhi, F. Monette, A. Azzouz, Effective and selective nitrate electroreduction into nitrogen through synergistic parameter interactions, Electrochimica Acta. 58 (2011) 276284.

[5] W.H. Organization, Rolling Revision of the WHO Guidelines for Drinking-Waters Quality, Nitrates and Nitrites in Drinking-Waters, World Health Organ. (2004). 
[6] D. Reyter, D. Bélanger, L. Roué, Nitrate removal by a paired electrolysis on copper and Ti/IrO2 coupled electrodes - Influence of the anode/cathode surface area ratio, Water Res. 44 (2010) 1918-1926.

[7] C. Polatides, G. Kyriacou, Electrochemical reduction of nitrate ion on various cathodesreaction kinetics on bronze cathode, J. Appl. Electrochem. 35 (2005) 421-427.

[8] V. Mateju, S. Cizinska, J. Krejci, T. Janoch, Biological water denitrification-A review, Enzyme Microb. Technol. 14 (1992) 170-183.

[9] G.E. Badea, Electrocatalytic reduction of nitrate on copper electrode in alkaline solution, Electrochimica Acta. 54 (2009) 996-1001.

[10] M. Zhou, W. Fu, H. Gu, L. Lei, Nitrate removal from groundwater by a novel threedimensional electrode biofilm reactor, Electrochimica Acta. 52 (2007) 6052-6059.

[11] Y. Wang, J. Qu, R. Wu, P. Lei, The electrocatalytic reduction of nitrate in water on $\mathrm{Pd} / \mathrm{Sn}-$ modified activated carbon fiber electrode, Water Res. 40 (2006) 1224-1232.

[12] J. Kim, M.M. Benjamin, Modeling a novel ion exchange process for arsenic and nitrate removal, Water Res. 38 (2004) 2053-2062.

[13] M. Li, C. Feng, Z. Zhang, X. Lei, R. Chen, Y. Yang, et al., Simultaneous reduction of nitrate and oxidation of by-products using electrochemical method, J. Hazard. Mater. 171 (2009) $724-730$.

[14] D. Reyter, G. Chamoulaud, D. Bélanger, L. Roué, Electrocatalytic reduction of nitrate on copper electrodes prepared by high-energy ball milling, J. Electroanal. Chem. 596 (2006) $13-24$.

[15] G. Pérez, A.R. Fernández-Alba, A.M. Urtiaga, I. Ortiz, Electro-oxidation of reverse osmosis concentrates generated in tertiary water treatment, Water Res. 44 (2010) 27632772. 
[16] K. Rajeshwar, J.G. Ibanez, Environmental electrochemistry: Fundamentals and applications in pollution sensors and abatement, Academic Press, 1997.

[17] I. Katsounaros, M. Dortsiou, G. Kyriacou, Electrochemical reduction of nitrate and nitrite in simulated liquid nuclear wastes, J. Hazard. Mater. 171 (2009) 323-327.

[18] M. Dortsiou, G. Kyriacou, Electrochemical reduction of nitrate on bismuth cathodes, J. Electroanal. Chem. 630 (2009) 69-74.

[19] H. Cheng, K. Scott, P.A. Christensen, Paired electrolysis in a solid polymer electrolyte reactor-Simultaneously reduction of nitrate and oxidation of ammonia, Chem. Eng. J. 108 (2005) 257-268.

[20] I. Katsounaros, D. Ipsakis, C. Polatides, G. Kyriacou, Efficient electrochemical reduction of nitrate to nitrogen on tin cathode at very high cathodic potentials, Electrochimica Acta. 52 (2006) 1329-1338.

[21] D. Reyter, D. Bélanger, L. Roué, Optimization of the cathode material for nitrate removal by a paired electrolysis process, J. Hazard. Mater. 192 (2011) 507-513.

[22] Y. Vanlangendonck, D. Corbisier, A. Van Lierde, Influence of operating conditions on the ammonia electro-oxidation rate in wastewaters from power plants (ELONITA ${ }^{\mathrm{TM}}$ technique), Water Res. 39 (2005) 3028-3034.

[23] K. Shimazu, R. Goto, K. Tada, Electrochemical reduction of nitrate ions on tin-modified platinum and palladium electrodes, Chem. Lett. 31 (2002) 204-205.

[24] J.W. Peel, K.J. Reddy, B.P. Sullivan, J.M. Bowen, Electrocatalytic reduction of nitrate in water, Water Res. 37 (2003) 2512-2519.

[25] H.L. Li, J. Chambers, D. Hobbs, Electroreduction of nitrate ions in concentrated sodium hydroxide solutions at lead, zinc, nickel and phthalocyanine-modified electrodes, J. Appl. Electrochem. 18 (1988) 454-458. 
[26] H. Li, D.H. Robertson, J.Q. Chambers, D.T. Hobbs, Electrochemical reduction of nitrate and nitrite in concentrated sodium hydroxide at platinum and nickel electrodes, J. Electrochem. Soc. 135 (1988) 1154-1158.

[27] D. Pletcher, Z. Poorabedi, The reduction of nitrate at a copper cathode in aqueous acid, Electrochimica Acta. 24 (1979) 1253-1256.

[28] O.A. Petrii, T.Y. Safonova, Electroreduction of nitrate and nitrite anions on platinum metals: A model process for elucidating the nature of the passivation by hydrogen adsorption, Int. J. Devoted Asp. Electrode Kinet. Interfacial Struct. Prop. Electrolytes Colloid Biol. Electrochem. 331 (1992) 897-912.

[29] G.E. Dima, A.C.A. De Vooys, M.T.M. Koper, Electrocatalytic reduction of nitrate at low concentration on coinage and transition-metal electrodes in acid solutions, J. Electroanal. Chem. 554 (2003) 15-23.

[30] D. De, J.D. Englehardt, E.E. Kalu, Cyclic Voltammetric Studies of Nitrate and Nitrite Ion Reduction at the Surface of Iridium-Modified Carbon Fiber Electrode, J. Electrochem. Soc. 147 (2000) 4224-4228.

[31] M. Da Cunha, J.P.I. De Souza, F.C. Nart, Reaction pathways for reduction of nitrate ions on platinum, rhodium, and platinum-rhodium alloy electrodes, Langmuir. 16 (2000) 771777.

[32] J.O.M. Bockris, J. Kim, Electrochemical treatment of low-level nuclear wastes, J. Appl. Electrochem. 27 (1997) 623-634.

[33] D. Reyter, D. Belanger, L. Roue, Study of the electroreduction of nitrate on copper in alkaline solution, Electrochimica Acta. 53 (2008) 5977-5984.

[34] K. Bouzek, M. Paidar, A. Sadílková, H. Bergmann, Electrochemical reduction of nitrate in weakly alkaline solutions, J. Appl. Electrochem. 31 (2001) 1185-1193. 
[35] Z. Macova, K. Bouzek, J. IvSerák, Electrocatalytic activity of copper alloys for NO 3reduction in a weakly alkaline solution, J. Appl. Electrochem. 37 (2007) 557-566.

[36] A.S. Lima, M.O. Salles, T.L. Ferreira, T.R.L.C. Paixão, M. Bertotti, Scanning electrochemical microscopy investigation of nitrate reduction at activated copper cathodes in acidic medium, Electrochimica Acta. 78 (2012) 446-451.

[37] M. Li, C. Feng, Z. Zhang, N. Sugiura, Efficient electrochemical reduction of nitrate to nitrogen using Ti/IrO2-Pt anode and different cathodes, Electrochimica Acta. 54 (2009) $4600-4606$.

[38] B.K. Simpson, D.C. Johnson, Electrocatalysis of Nitrate Reduction at Copper-Nickel Alloy Electrodes in Acidic Media, Electroanalysis. 16 (2004) 532-538.

[39] M. Li, C. Feng, Z. Zhang, Z. Shen, N. Sugiura, Electrochemical reduction of nitrate using various anodes and a $\mathrm{Cu} / \mathrm{Zn}$ cathode, Electrochem Commun. 11 (2009) 1853-1856.

[40] N. Fan, Z. Li, L. Zhao, N. Wu, T. Zhou, Electrochemical denitrification and kinetics study using $\mathrm{Ti} / \mathrm{IrO} 2-\mathrm{TiO} 2-\mathrm{RuO} 2$ as the anode and $\mathrm{Cu} / \mathrm{Zn}$ as the cathode, Chem. Eng. J. 214 (2013) 83-90.

[41] G. Chamoulaud, D. Floner, C. Moinet, C. Lamy, E.M. Belgsir, Biomass conversion II: simultaneous electrosyntheses of furoic acid and furfuryl alcohol on modified graphite felt electrodes, Electrochimica Acta. 46 (2001) 2757-2760.

[42] S.J. Tabatabaei, M. Yusefi, J. Hajiloo, Effects of shading and NO3:NH4 ratio on the yield, quality and N metabolism in strawberry, Sci. Hortic. 116 (2008) 264-272.

[43] T.A. Nell, J.E. Barrett, Nitrate-ammonium nitrogen ratio and fertilizer application method influence bract necrosis and growth of poinsettia, HortScience. 20 (1985) 1130-1131. 
[44] T. Sadat Taghavi, M. Babalar, The effect of nitrate and plant size on nitrate uptake and in vitro nitrate reductase activity in strawberry (Fragaria $\times$ ananassa cv. Selva), Sci. Hortic. 112 (2007) 393-398.

[45] P. Iyer, M.A. Bruns, H. Zhang, S. Van Ginkel, B.E. Logan, H2-producing bacterial communities from a heat-treated soil inoculum, Appl. Microbiol. Biotechnol. 66 (2004) $166-173$.

[46] J. Masset, S. Hiligsmann, C. Hamilton, L. Beckers, F. Franck, P. Thonart, Effect of pH on glucose and starch fermentation in batch and sequenced-batch mode with a recently isolated strain of hydrogen-producing Clostridium butyricum CWBI1009, Int. J. Hydrog. Energy. 35 (2010) 3371-3378.

[47] M.B. Salerno, W. Park, Y. Zuo, B.E. Logan, Inhibition of biohydrogen production by ammonia, Water Res. 40 (2006) 1167-1172.

[48] X. Wang, B. Jin, D. Mulcahy, Impact of carbon and nitrogen sources on hydrogen production by a newly isolated Clostridium butyricum W5, Int. J. Hydrog. Energy. 33 (2008) 4998-5005.

[49] D. Floner, F. Geneste, Homogeneous coating of graphite felt by nickel electrodeposition to achieve light nickel felts with high surface area, Electrochem. Commun. 9 (2007) 22712275 .

[50] C. Moinet, Electrosynthèse organique en continu. Méthodes directes et indirectes, J. Phys. IV. 04 (1994) C1-175-C1-184.

[51] A.D. Eaton, M.A.H. Franson, Standard methods for the examination of water \& wastewater, Amer Public Health Assn, 2005.

[52] D.S. Frear, R.C. Burrell, Spectrophotometric method for determining hydroxylamine reductase activity in higher plants, Anal. Chem. 27 (1955) 1664-1665. 
[53] A.E. Greenberg, L.S. Clesceri, A.D. Eaton, Standard Methods for the Examination of Water and Wastewater, American Public Health Association, Washington, DC, (1992).

[54] A. Boisson, P. de Anna, O. Bour, T. Le Borgne, T. Labasque, L. Aquilina, Reaction chain modeling of denitrification reactions during a push-pull test, J. Contam. Hydrol. 148 (2013) $1-11$.

[55] A. Storck, M.A. Enriquez-Granados, M. Roger, F. Coeuret, The behaviour of porous electrodes in a flow-by regime-I. theoretical study, Electrochimica Acta. 27 (1982) 293301.

[56] T. Doherty, J.G. Sunderland, E.P.L. Roberts, D.J. Pickett, An improved model of potential and current distribution within a flow-through porous electrode, Electrochimica Acta. 41 (1996) 519-526. 


\section{Figure Captions}

Fig. 1. Schematic diagram of the flow cell, a, porous electrode; b, counter electrodes (platinum grids); $\mathrm{c}_{1}$, cationic membrane; $\mathrm{c}_{2}$, anionic membrane; d, electrolyte inlet; e, electrolyte outlet ; PW, power supply.

Fig. 2. SEM images of metal coated graphite felts a - Nickel coated graphite felt

b, c, d - Copper electrodeposited on nickel modified graphite felt

Fig. 3. Effect of current and $\mathrm{pH}$ on current efficiency.

pH 4.8

$\boldsymbol{\Delta} \mathrm{pH} 7.2$ 


\section{Table 1}

Summary of optimal experimental conditions for copper plating on nickel modified graphite felt

\begin{tabular}{cc}
\hline Parameters & Optimal conditions \\
\hline$\left[\mathrm{Cu}^{2+}\right]$ & $3 \times 10^{-2} \mathrm{M}$ \\
initial $\mathrm{pH}$ & $4-5$ \\
Flow rate & $5 \mathrm{~mL} \mathrm{~min}^{-1}$ \\
Applied current & $0.1 \mathrm{Acm}^{-3}$ \\
On pulse & $15 \mathrm{~s}^{-5}$ \\
Off pulse & $35 \mathrm{~s}$ \\
$\% \mathrm{CE}$ & $50 \%$ \\
\hline
\end{tabular}




\section{Table 2}

Experimental conditions to achieve the electrodeposition of copper on nickel modified graphite felt

\begin{tabular}{ccccccccc}
\hline Experiment & $\begin{array}{c}{\left[\mathbf{C u}^{2+}\right]} \\
\mathbf{m o l ~ L}^{-1}\end{array}$ & $\begin{array}{c}\text { On } \\
\text { pulse } \\
\mathbf{t}_{\text {on }}\end{array}$ & $\begin{array}{c}\text { Off } \\
\text { pulse } \\
\mathbf{t}_{\text {off }}\end{array}$ & $\mathbf{t}_{\text {off }} / \mathbf{t}_{\text {on }}$ & $\begin{array}{c}\text { On pulse } \\
\text { total time }\end{array}$ & $\begin{array}{c}\text { Full electrolysis } \\
\text { Time }\end{array}$ & Electrode aspect & \% CE \\
\hline 1 & $10^{-2}$ & $7 \mathrm{~s}$ & $10 \mathrm{~s}$ & 1.4 & $2 \mathrm{~h} 20 \mathrm{~min}$ & $5 \mathrm{~h} 40 \mathrm{~min}$ & Poor deposit & 24 \\
3 & $3 \times 10^{-2}$ & $7 \mathrm{~s}$ & $10 \mathrm{~s}$ & 1.4 & $2 \mathrm{~h} 20 \mathrm{~min}$ & $5 \mathrm{~h} 40 \mathrm{~min}$ & Metallic crust & 65 \\
4 & $10^{-2}$ & $10 \mathrm{~s}$ & $10 \mathrm{~s}$ & 1 & $6 \mathrm{~h} 11 \mathrm{~min}$ & $13 \mathrm{~h}$ & Metallic crust & 13 \\
& $3 \times 10^{-2}$ & $15 \mathrm{~s}$ & $35 \mathrm{~s}$ & 2.3 & $4 \mathrm{~h}$ & $13 \mathrm{~h}$ & $\begin{array}{c}\text { Homogeneous } \\
\text { film of cooper }\end{array}$ & 58 \\
\hline
\end{tabular}




\section{Table 3}

Effect of flow rate and $\mathrm{pH}$ on the electrochemical reduction of nitrate to ammonium. (Initial nitrates concentration $=3 \mathrm{~g} \mathrm{NO}_{3}^{-} \mathrm{L}^{-1}$; electrolyzed volume $=1$ liter $)$.

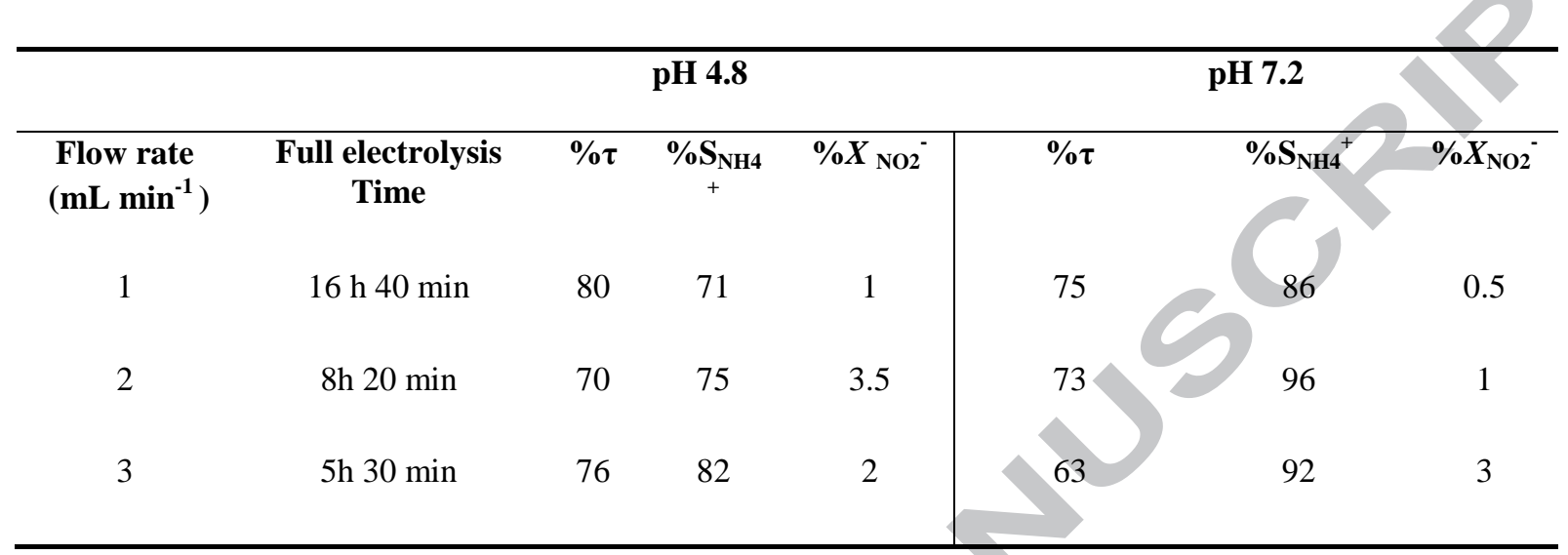




\section{Table 4}

Effect of current and $\mathrm{pH}$ on the electrochemical reduction of nitrate to ammonium. $\left(R_{i}=i_{\text {app }} / i_{\text {th }}\right.$; initial nitrate concentration $=3 \mathrm{~g} \mathrm{NO}_{3}^{-} \mathrm{L}^{-1}$; flow rate $=2 \mathrm{~mL} \mathrm{~min}^{-1} ; i_{\text {th }}=1.24 \mathrm{~A}$ ).

\begin{tabular}{|c|c|c|c|c|c|c|c|c|c|}
\hline \multirow[b]{2}{*}{$\begin{array}{l}i_{\text {app }} \\
(\mathbf{A})\end{array}$} & \multirow[b]{2}{*}{$\boldsymbol{R}_{i}$} & \multicolumn{4}{|c|}{ pH 4.8} & \multicolumn{3}{|c|}{ pH 7.2 } & 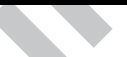 \\
\hline & & $\% \tau$ & $\% \tau_{\text {app }}$ & $\% \mathrm{~S}_{\mathrm{NH} 4}^{+}$ & $\% X_{\mathrm{NO} 2}^{-}$ & $\% \tau$ & $\% \tau_{\text {app }}$ & $\% \mathrm{~S}_{\mathrm{NH} 4}$ & $\% X_{\mathrm{NO}^{-}}^{-}$ \\
\hline 0.64 & 0.5 & 50 & 100 & 40 & 1.5 & 46 & 92 & 60 & 0.5 \\
\hline 0.93 & 0.75 & 68 & 90 & 60 & 2.5 & 66 & 88 & 79 & 0.5 \\
\hline 1.24 & 1 & 70 & 70 & 75 & 3.5 & 73 & 73 & 96 & 1 \\
\hline 1.55 & 1.25 & 75 & 75 & 68 & 3.5 & 79 & & 96 & 1.5 \\
\hline 1.86 & 1.5 & 82 & 82 & 62 & 4 & 83 & 83 & 93 & 1.5 \\
\hline
\end{tabular}



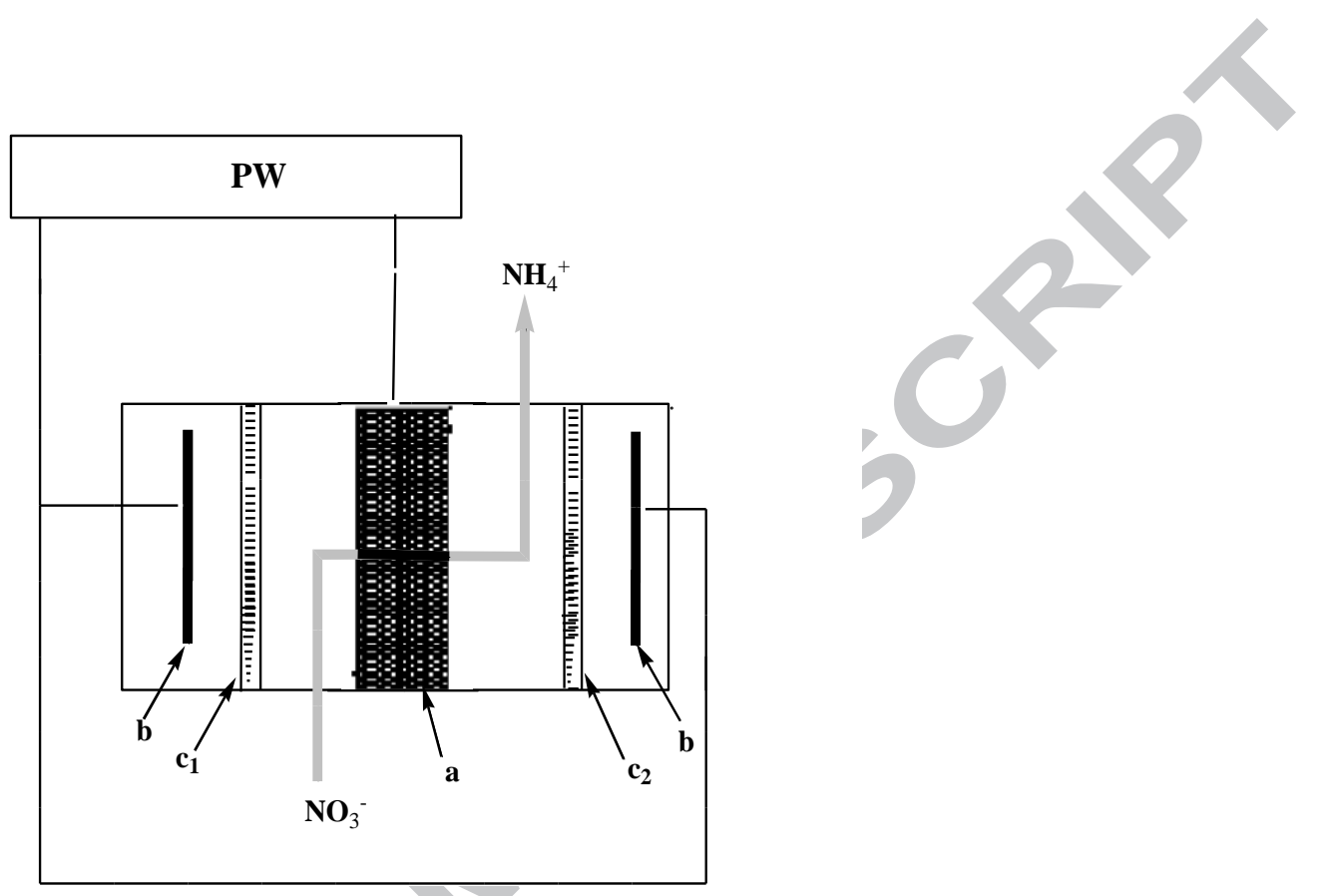

Fig.1 
a

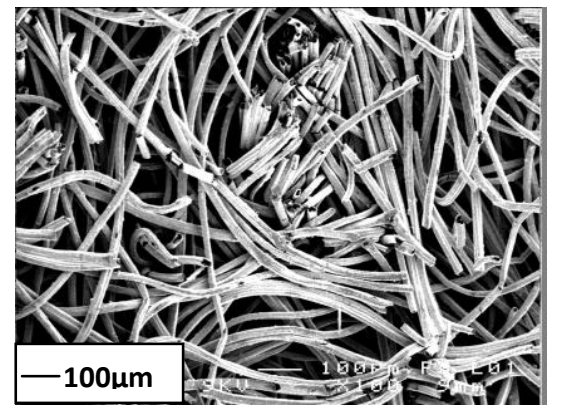

c

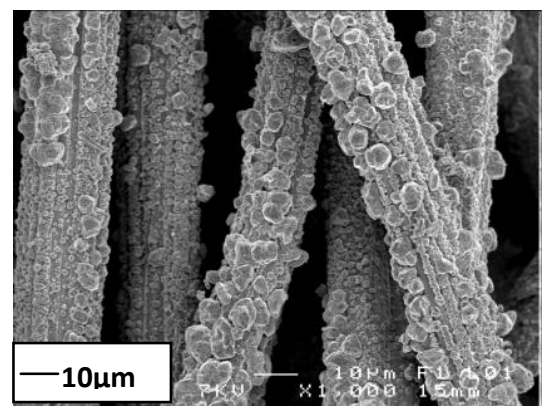

b

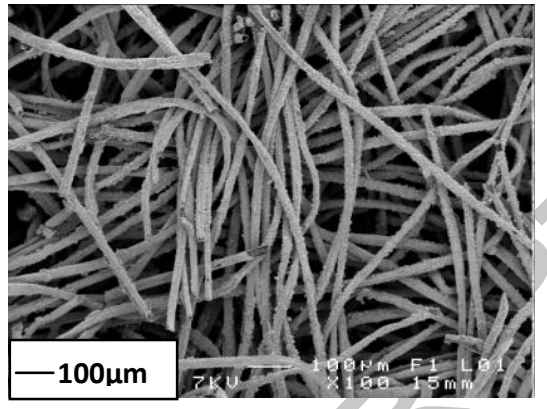

d

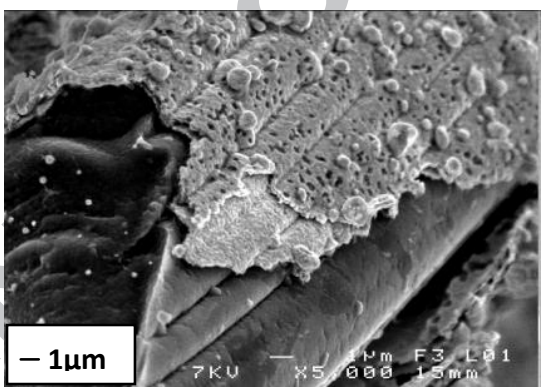

Fig. 2. 


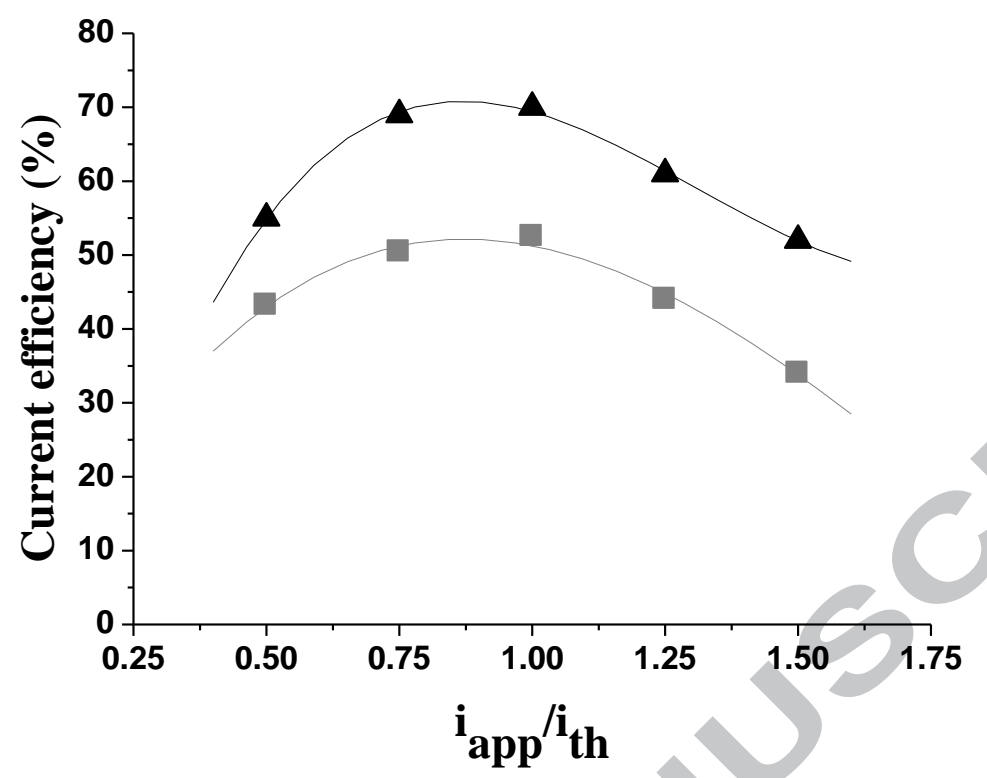

Fig. 3. 


\section{Research Highlights}

- A novel porous copper electrode of high surface areas and low densities was prepared

- The copper cathode was examinated for electroreduction of nitrate to ammonium

- $\quad$ selective and quantitative reduction of nitrate was obtained in neutral solution

- High chemical yields and current efficiencies toward ammonium formation was recorded

- $\quad$ Recycling of nitrates as an abundant and inexpensive source of ammonium 